\title{
The Transformative Dragon The Construction of Social Identity and the Use of Metaphors during the Nordic Iron Age.
}

\author{
Birgitta Johansen
}

\begin{abstract}
This article deals with how people during the Iron Age constructed their social identity, how they matured and became men and women - a process connected with the ownership and cultivation of landed property. Three different types of ancient monuments - stone walls, hillforts and runestones - are discussed in this context. The theoretical point of departure is that monuments have visual messages of their own, not necessarily identical with how they have been used, and that the metaphor is a useful analytical tool.
\end{abstract}

Birgitta Johansen, Department of Archaeology, Stockholm University, S-10691 Stockholm, Sweden.

The main character in this essay is the dragon or serpent. I use this imaginary reptile to illuminate the visual and conceptual connection between stone walls, hill-forts and runestones. These ancient monuments have in essence no "functional" nor chronological connection with each other. They can, however, be treated as material expressions of a world of ideas, and of the life-world, during the Nordic Iron Age and early Middle Ages (the period I am interested in is ca. 200-1100 A.D.). My reason for comparing these types of ancient monuments is that all three can be connected with the cultivation and ownership of land as well as their change over time. Perhaps the most surprising monument in this context is the hill-fort. It is consequently discussed in a separate chapter.

The question at issue is, how do spatial and social structures co-operate, or put more concretely, what is the relationship between landscape and life? To investigate this I will analyse different types of boundaries as well as gender classifications. My interest is focused on how these structures have been constructed in relation to one another, but also how they have been strengthened by their mutual relationship. My aim is to show how gender and other delimitations, in this case the rights to, the ownership of, or the control of land can be studied as two interrelated themes.

Dragon and serpent/snake are often used as synonyms in the literary sources (see below). Here I usually use the word "dragon" for both of them. No essential difference seems to have been made between snake and dragon; they are both reptiles, but the dragon has also attributes from, for example, lizards and carnivores. Pictures of dragons (i.e. serpents and dragons) are found on Gotlandic picture stones from ca. 400-1100 A.D., on Viking Age runestones, and on different types of objects from the Iron Age. The dragon is also a very common creature in the early medieval Romanesque iconography (cf. Karlsson 1976:167).

MEN, WOMEN, AND THE DRAGON In this section I will give a presentation of 


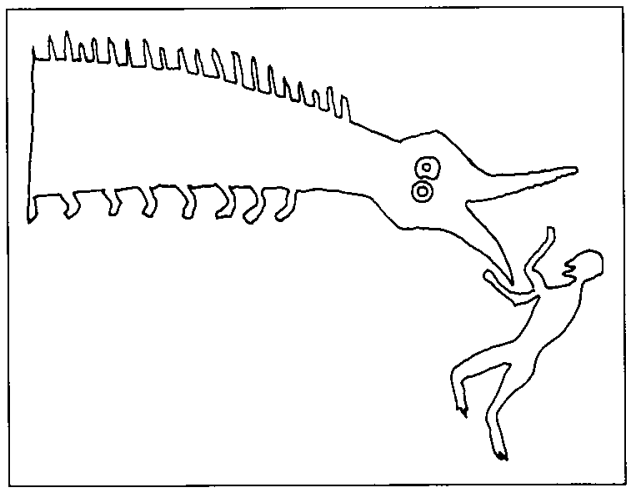

Fig. 1. An unarmed man fighting with a dragon on a picture stone, dated to 400-600 A.D. Found in a grave in Austers, Hangvar parish, Gotland (cf. Fig. 3). Drawing after Nylén \& Lamm 1987.

the dragon and its attributes, as well as its relationship to men and women and their respective social roles. It is, however, first necessary to examine the literary sources that mention dragons.

Perhaps the most important text is The Völsunga Saga (1991). The oldest version is found in the manuscript called The Poetic (or Older) Edda, from ca. 1270 (Den poetiska eddan 1993). Snorre's Edda, from ca. 1220, has a "summary" of this story which is probably based on older, now lost, "Eddas" (1978). The historical essence is considered to reflect the fate of the kingdom of Burgundy during the fifth century A.D. (Hedeager 1991:135). Several images on different objects from the Viking Age and the early Middle Ages have been interpreted as illustrations of this story (Margeson 1980:183 pp and quoted lit., Andrén 1989:299 pp). It seems reasonable to assume that these stories, or rather the different motifs of these stories, were known and used in the Nordic countries from the sixth century onwards (cf. Hedeager 1991:133). On at least one Gotlandic picture stone (Fig. 1) from the sixth century A.D. an unarmed man and a dragon confront each other (cf. Beowulf), and this does not have to be the hind limit. It is even probable that this is an ancient Indo-European myth (cf. the works of Georges Dumézil, e.g. 1973, Ström 1990: $43 \mathrm{pp}$ ). The popularity of this story through many centuries shows alone the power of the motifs that it is composed of.

I will focus on four motifs in The Völsunga Saga, of which the most well known and depicted is the hero Sigurd and his fight with the dragon Fafner, who is the watch over a huge golden treasure (from the beginning a wergild) (Fig. 2). The second motif is Sigurd's conquest of the valkyrie Brynhild. She is protected by fire on a mountain. The third is Gunnar in the snake-pen. The fourth is the violent and tragic end, whereby Gudrun kills her and Atle's two small sons. She then kills him and finally sets his hall on fire, with him and his men within.

Through The Völsunga Saga, Beowulf, Saxo, etc. we get the historical view of the Migration period (ca. 400-550 A.D.) during the Viking Age and early Middle Ages; it is painted in a mystic and heroic shimmer. In Snorre Sturluson's Ynglinga Saga (it has the song Ynglingatal as an exemplary) the origins of the royal dynasty, the Ynglingar, are traced back to this period. Owing to this, a study of the Migration period hill-forts becomes an amalgamation of several different horizons constructed through one another; we come to know the Migration period by means of the Viking Age and the Middle Ages. We will also come to understand the later periods through their historical constructions. Both time and historical understanding are in this way social and historical products.

A perpetually recurring theme is, as mentioned, the dragon as a guardian (watch) and as associated with riches of different kinds. The dragon is depicted, for example, as the guardian of valuables, often precious metals. Ancient grave monuments (where treasures were believed to be hidden) had names such as Drakarör (The Cairn of the Dragon) and Ormkullen (The Snake Mound), and places 
where treasures had been found were called e.g. Ormkilen (The Wedge-shaped Snake Lot). The Viking Age long ships that brought home the treasures are compared to the dragon by means of kenningar (see below); the sails were named dragon wings and the ships simply dragon ships, or they had proper names such as Ormen Lange (Long Serpent). The women in the stories can be guarded, or even let them selves be guarded, by dragons just as other things of value. It is in this context conspicuous that the females are compared to jewellery. The daughters of the goddess Freja - Hnoss and Gersimi - had, for example, names that alluded to beautiful and precious things, gems. Saxo tells us about the Swedish princess Thora: she was guarded and protected by two serpents, who were finally killed by the cunning suitor Ragnar Lodbrok (1985:Bd2:106 p). He also tells a similar story about another Swedish princess, Alvilde, whose father gave her a dragon and a viper to raise so that they would protect her chastity (1985:Bd2:20). Variations on this story are also documented in the folklore concerning hill-forts in the provinces of Sö- dermanland and Östergötland (Tora Borgarhjort, Nordén 1929:191 pp). It is otherwise more common with stories about treasures guarded by dragons in hill-forts. The splendidly equipped female grave from Oseberg in Norway (early 9 th century) contains several objects with dragon ornaments.

There is a radical difference in the dragon's pattern of behaviour in relation to men and women respectively; the dragon is dangerous to men and it is men who fight with it (Figs. 1-4), but it protects women. There are a few pictures in which the dragon and the men seem to be "on the same side" (cf. helmet-plate from grave 7, Valsgärde, Uppland, in Arwidsson 1977:Abb, 115), but there are plenty of mountings and buckles in the shape of dragons belonging to the male equipment. Significantly enough, however, it is only women who hold serpents in their hands in the Iron Age pictures (Figs. 6-8). The dragon is also a danger to the male gods. The punishment of Loki (the instigator of the death of Balder) was to be fettered and tormented by the venom from a serpent and Tor's fight with the Midgårdsorm (The Ser-

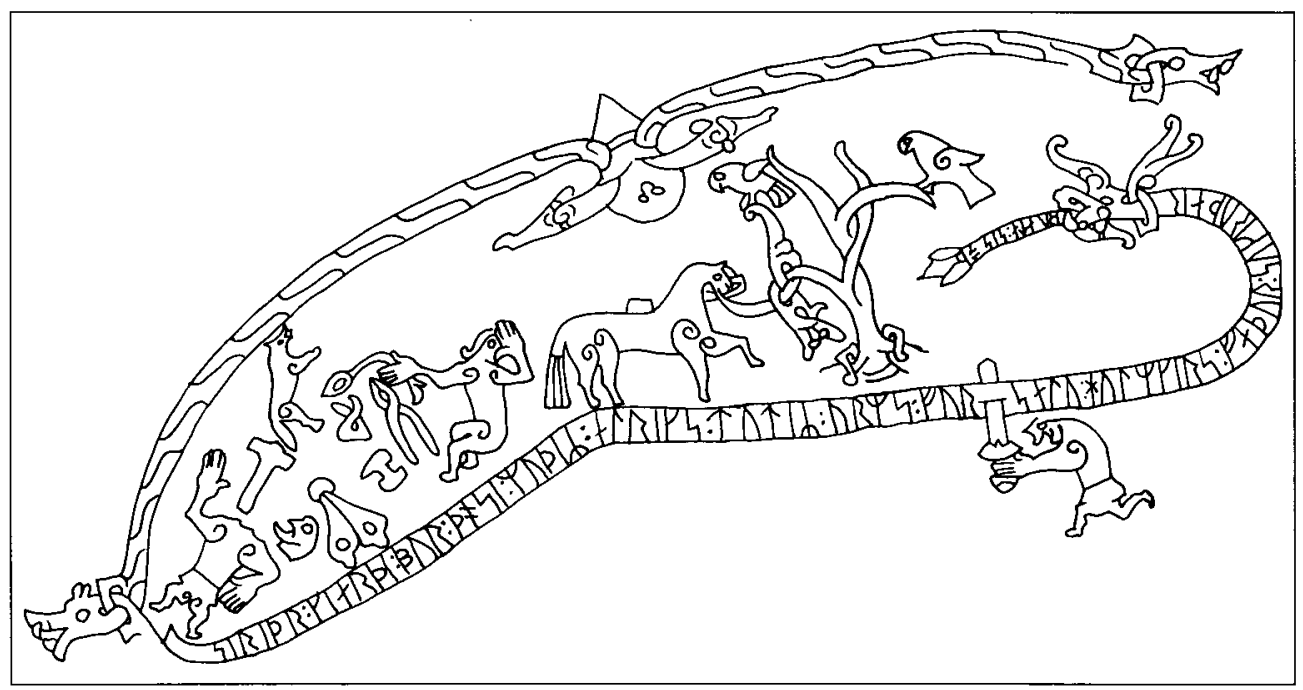

Fig. 2. The hero Sigurd and his fight with the dragon Fafner in a runic carving from the Viking Age on Ramsundsberget in Sundby parish, Södermanland. Drawing after Runstenar i Södermanland. 


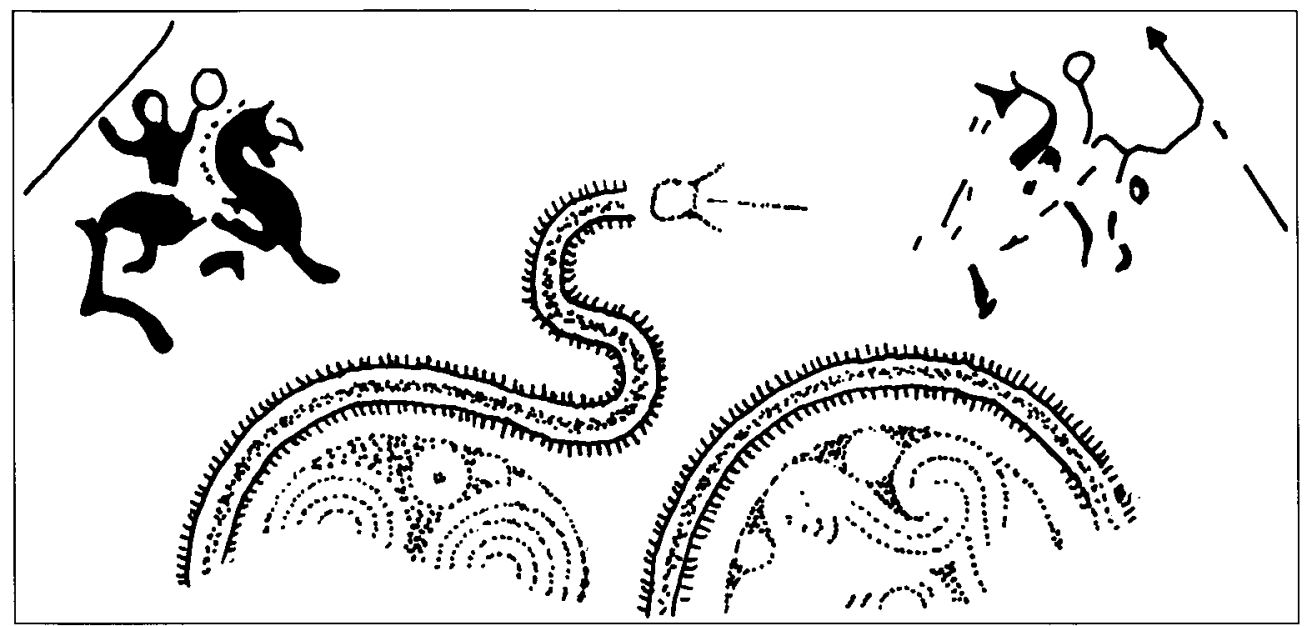

Fig. 3. Picture stone, dated to 400-600 A.D., from Martebo church, Gotland. Two, possibly young, men on horses with spears/lances and shields (?) in their hands are attacking a dragon. According to the Roman historian Tacitus, the young Germanic men were equipped with a spear and a shield and only later received a sword. This information is supported by the equipment found in excavated graves. Drawing after Nylén \& Lamm 1987.

pent of Midgård - the Middle Farm, fig. 9) is very well known.

On gold foil figures (guldgubbar, the Migration to Viking periods) depicting a couple, the females are sometimes holding an oblong object in their hands. It is placed between the man and the woman and it has usually been compared to a staff or a stalk/branch. I believe that the staff/stalk, at least in some respects, could be associated with the dragon. For instance, the Midgårdsorm also has the name Jörmungandr which, according to one interpretation, means "storstaven, den väldiga staven" (Snorre's Edda 1978:138, trans. the Great Staff, the Mighty Staff, cf. Mittner 1955:40). Some support is also given by the fact that the most prominent feature of the völva is her staff. The völva was a prophetic seeress who could see into that which was hidden and beyond time. She forecast the destiny of man. Even the name völva is derived from Volr=stav. The ability to see beyond connects the völva with the serpent, who can move under the earth in that which is hidden from man (cf. Hnitbjörg below).

In the stories the value and dignity of an unmarried woman is connected with her chastity. When Gunvor, the sister of the Danish (fairy) king Frode Fredegode, was threatened by a lecherous man, she let herself be locked up in a maiden's bower surrounded by a rampart and guarded by thirty men (Saxo 1985:Bd1:148). Gunnar's painful punishment in the snake-pen (in The Volsunga Saga) could therefore perhaps be seen in the light of his offence against Brynhild. He could not single handedly penetrate the fire that protected Brynhild. The hero Sigurd, who in the guise of Gunnar is wedded to Brynhild, had to help him. When Brynhild discovered the deceit, she incited Gunnar to kill Sigurd. She had been to bed with two men, neither of whom was really her husband, that is, her chastity had been defiled and her honour offended. Finally she took her own life. The conquering of a woman is also the theme in 


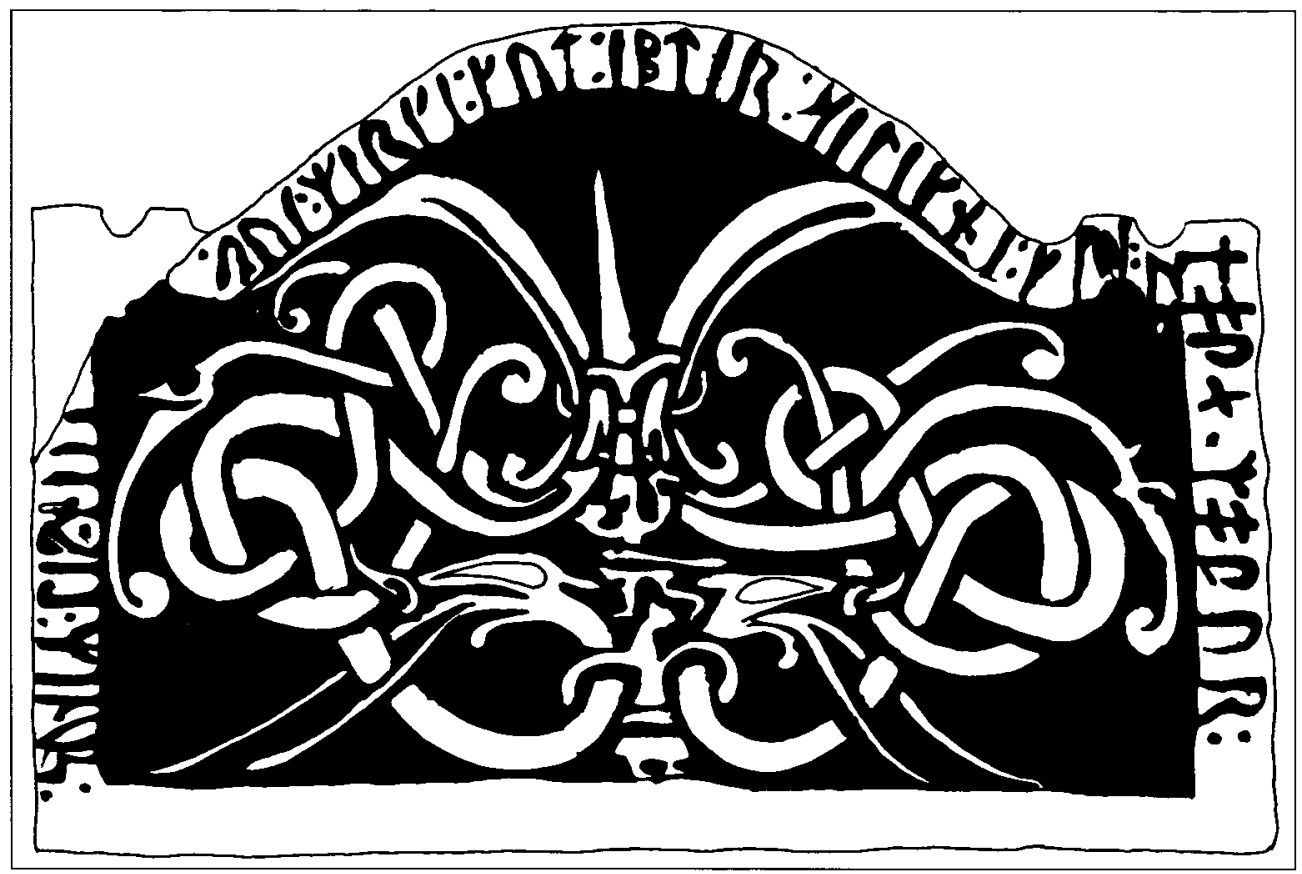

Fig. 4. One of four picture stones from a cist from the late Iron Age, Ardre church, Gotland. This kind of cist was probably only erected over women. In the middle is an attacking man armed with a spearl lance. Below is a woman holding her arms around two dragons. Drawing after Nylén \& Lamm 1987.

the Edda poem Skirnismál: Gerd, the reluctant daughter of a giant, is by means of threats and gifts persuaded to marry the god Frö. The couple known from the gold foil figures is supposed to represent this divine wedding. This Norse hierogamy myth has many layers. It has been interpreted as fecundity conceptions as well as the Norse ideology of kingship, the basis for the royal family (Steinsland 1990:82 pp). On another level the couple illustrates a meeting between heaven and earth, between the sovereign and his territory (ibid:86). War for conquest (of territory) and the rape of women of the besieged are furthermore two motifs that occur. These motifs could probably have had a fortifying effect on each other (cf. Damsholt 1985: 125). The conquering of a woman (and preferably a virgin) and thereby often land is on the whole a recurring motif of Saxo's. The folktale tells us about the smart and brave young lad who wins the princess and half the kingdom.

A structure that is based on the opposition between, and union of, the sexes can now be discerned. The woman is protected by, and associated with, the dragon and the fire; the man with the aggressor, the conqueror. This may seem a traditional picture with an active man and a passive woman. I do, however, believe that the man has to show himself worthy by overcoming a great danger. And besides, the young woman is defending herself almost as actively as the man is attacking. The chaste (and young) woman seeks protection on a mountain - in a hill-fort - is protected by fire - and/or arms herself. The woman is, however, associated with a life 
connected with one place, the stationary and internal. The man is associated with an active and external life. The woman is also associated with the selected and protected space, for example, the farm - the home - the earth. The fire that protects the woman can be comprehended as a development of the domestic hearth, the fire that takes and gives life. The burnt stone splinters in hill-forts and in the female graves (see below) can also be found on the settlement-sites, in the hearths within the houses. The fire has therefore the same ambiguous character as the dragon. Consequently The Völsunga Saga ends with Gudrun burning up her husband, after first having killed her sons and thereby ended the survival of the family. The females are associated with the beginning of life and its end, with that which is concealed. The men are associated with the life between birth and death, with that which is visible. This is in accordance with the female goddesses spheres of action and competence. Freja, who is the most distinguished, is a fecundity goddess, but she is also tied to death; one half of the warriors that fell in combat belonged to her (cf. Egil Skallagrimsson's Saga 1979:216). Female figures like disor, valkyrior, völvor and nornor are also associated with birth, death, concealed knowledge, and destiny or wyrd (cf. Brendalsmo \& Rothe 1992:101, Mittner 1955). There are no corresponding male figures. The tradition of seidr (cf. shamanism) was furthermore unmanly and the men who practised it were dressed up in women's clothes (Grambo 1989 in Odner 1992:138), something that was surely not a coincidence (Odner 1992:139). The youth could furthermore be aroused, both spiritually and physically, by a woman or by the love of/lust for a woman, for example, in the story about the hero Helge Hjörvardsson (Den poetiska eddan 1993:177, cf. kolbitr by Meulengracht Sørensen 1993:219-220). The virgin/valkyrie in the stories can be seen as a "preliminary stage" to womanhood. In the poetry there is thus a motif of development that corresponds to the maturing of human beings both physically and mentally. The active metaphor in a continued interpretation is therefore the establishment of an identity, the process of becoming adult (and mature) or from child to adult. This can be apprehended as a form of rite de passage, a transition from one stage to another (cf. Odner 1992:133 and quoted lit.).

During the Middle Ages the roles changed, at least in the religious context. But in popular belief the dragon was still a helper against for example, illness, and it is also known as a husorm, a snake kept and fed at the farm (cf. Karlsson 1976:170 and quoted lit.). The dragon now became a physical threat to the woman, who was passive and needed to be saved from it (cf. the legend of Saint George and the dragon as well as St. Margaret from Antiokia, Gilchrist 1994: 181). The dragon is usually associated with something evil, greedy and voluptuous. In the northern porch of the early medieval church in Väte, Gotland there are, for example, two dragons suckling a woman. This motif has been interpreted as Luxuria, that is, the Voluptuousness (Fig. 10). And one need only remember the serpent who made Eve persuade Adam to eat the fruit of knowledge.

To sum up, the dragon has certain characteristics, and they are to watch and to protect, to delimit and to distinguish, to exceed and to transform.

\section{GENDER}

Gender is by many researchers understood as a primary theme in the social construction of reality, but they usually emphasise that this concept cannot be regarded as unitary and invariable. Neither have the historical gender relations been static (Conkey \& Gero 1991:8 pp and quoted lit.). The concept of gender can be explained as the social and cultural construction of difference between different "biological" groups of humans. 
Thus, the social sex and the biological sex need not be the same thing. People use biological differences in the construction of the social reality (and perhaps first and foremost sexual such) to create social differences. The only problem is, that it is not obvious how the biological differences should be apprehended. We cannot postulate that the body has an evident identity. Tim Yates' way of handling this is by the concept "the body without organs" (1993:55 and quoted lit.). I have modified this concept somewhat to the body without identity. This means that feminine or masculine identity is something that needs to be acquired, it must be furnished to the body. The male and female sexual organs respectively, are therefore necessary but not sufficient prerequisites (ibid:66, 69). In his dissertation on the Icelandic sagas, Preben Meulengracht Sørensen states that a

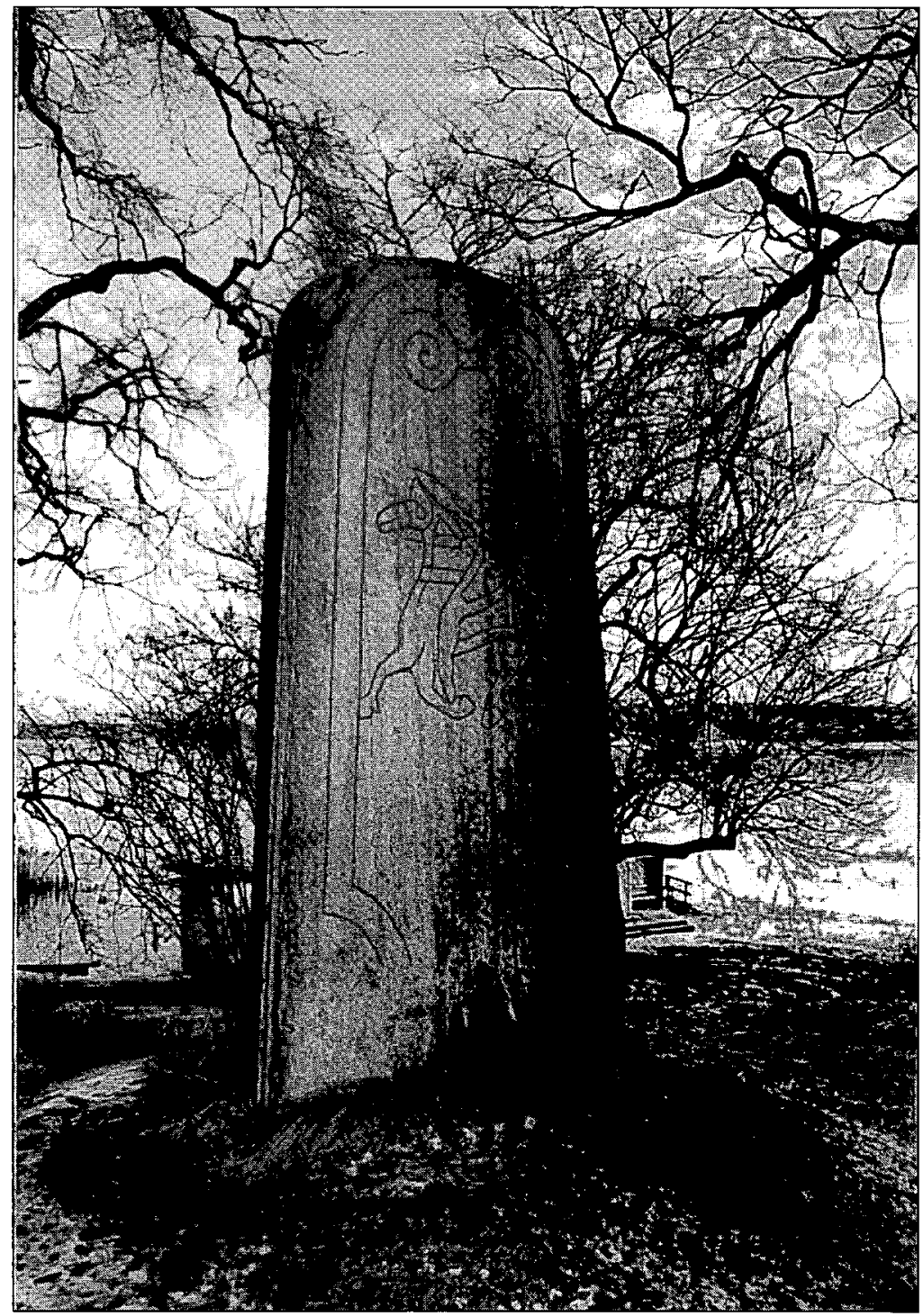

Fig. 5. A Viking Age runestone from Skokloster church in Uppland. On the side without an inscription a man is equipped with a lance, and on the other side, with the runic inscription commemorating him, the man is equipped with a sword. This could perhaps be repre. sentations of him as young and as mature.

Photo Björn Varenius. 
human being of male sex does not become a man by virtue of his biological development from child to adult. He must, by means of his conduct during the transition phase between youth and adult, show that he has the physical and psychological abilities of an adult man. And the most important and distinct expression for obtained status was marriage (1993:220, cf. ibid:225). Of interest for the following discussion is thus how an individual acquired "its" gender during the late Nordic Iron Age.

The issue at stake is not only the giving of new and unconventional spheres of action to men and women. It is also a question of examining how the "traditional" spheres have been evaluated. For instance from a "war perspective" this article could be about hill-forts manned with young, perhaps unmarried women, a kind of valkyries, that had fought and fallen and then been buried at the scene of action. The only difference between this interpretation and traditional hill-fort research would be that men were switched out against women. We would understand just as little as before about how ancient peoples created a world to live in. And there would have been no incentive to question the desig-

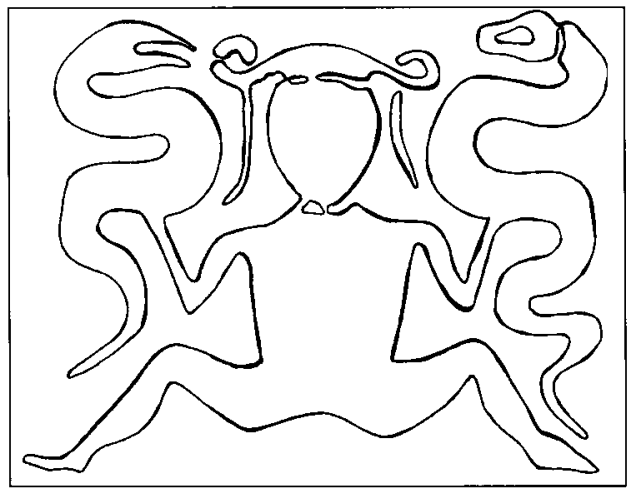

Fig. 6. Detail of the picture stone from Smiss in När parish, Gotland. It depicts a woman holding two serpents. The stone, which was recovered from a cemetery, is dated to 400-600 A.D. Drawing after Nylén \& Lamm 1987. nating of hill-forts solely as fortificative war structures (see below). The power of the gender perspective can, from my point of view, be examined first when it is studied in relation to other themes, not when it is developed in isolation. Therefore I will try to indicate how the social and historical constructions of gender during the late Nordic Iron Age can be paralleled and compared with other structurings of the life space, for example, how domains that seem to be completely distinct on a structural level are mutually related and dependent.

\section{THE HILL-FORTS}

Many hill-forts were erected during the late Roman Iron Age and the Migration period (though there are both older and younger hillforts in Sweden) and it is these that are of interest here. This is a period that has usually been characterised as troubled by migrations and plagues, and as a consequence it is thought that the settlements were abandoned. I would, however, like to see a different explanation: the restructuring of the inhabited landscape was caused by changes in social and political structures, not by single events. This view makes it possible to explain the erection of the hill-forts in connection with the changes in the ownership of and/or rights to land.

The hill-forts of the Mälar valley are seldom impressive or labour-intensive structures. Many of them have rather modest walls (ramparts) and they are not built of more stone than ordinary stone walls from the last two centuries. However, single structures do have walls that are comprehensive and several meters high. Earlier interpretations of hill-forts have often been limited to a "functional" and warlike sphere. These interpretations cannot explain why so many hill-forts have modest proportions and a symbolic character, and structures that do not fit in have usually been dispatched to a "cult" domain of an unknown nature. In this warlike scenario, women have been if not 
almost completely absent then assigned to the role of passive consumers of hill-fort protection. The men, on the other hand, are present as the active defenders and offenders. The respective roles of the sexes can be summarised in the words "defenceless/absent" and "assailant/present". I do not deny that a theme of conflict and violence is certainly part of the understanding of the hillfort group, even though I won't expound it in this context. What I am opposed to is the warlike one-sidedness and the absence of women. Consequently, one purpose is to display a female principle hitherto underestimated but manifestly present in the hillforts, and another is to demonstrate that the material culture cannot be understood solely through functional determinations.

\section{THE CONCEPT OF HILL-FORT}

The categorisations of ancient monuments that we use today seem to have a discrete nature, but we can be sure that they have nothing, or very little, in common with the ancient concepts. The rather unusual definitions of hill-forts in earlier hill-fort research are based themselves on "biased assumptions" or preconceptions of them as fortificative, strategic and tactical. These in turn are dependent upon older, not seldom folklore, traditions and a visual likeness with later military structures (Johansen \& Pettersson 1993). If we instead proceed from the morphology of the hill-forts then the concepts delimit and distinguish and restriction/ control of a selected area (Johansen \& Pettersson 1993:11) are just as descriptive. And they are definitely less burdened with earlier interpretations. These concepts are, however, in no way neutral, but are loaded with different types of associations. This emphasis on hill-fort morphology should not be interpreted as if all structures labelled as such could also automatically be given the same interpretation. Hill-forts have been built for different reasons and used in different ways. There is nothing in the construction itself that

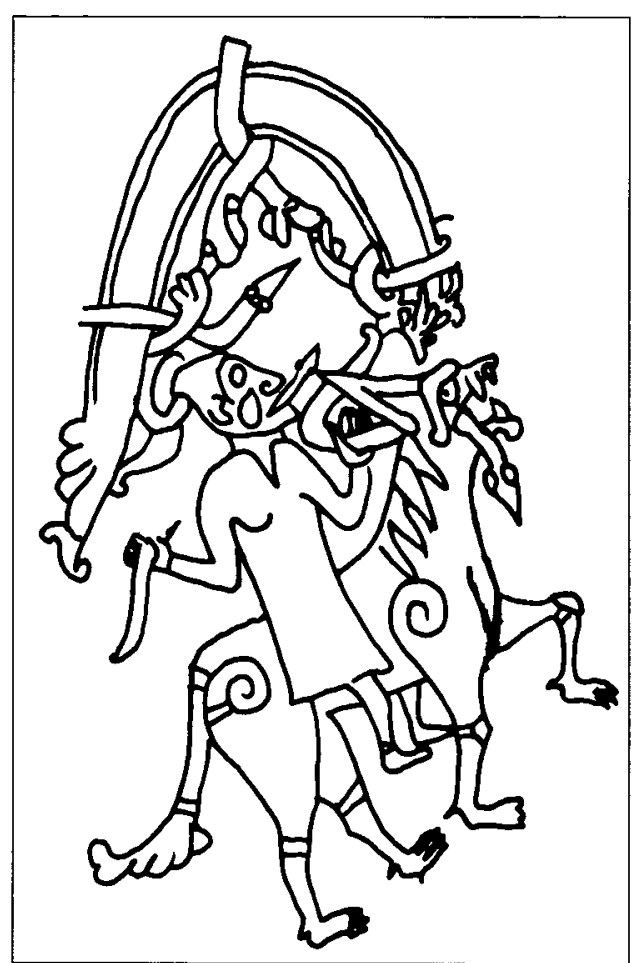

Fig. 7. The female giant Hyrrokkin riding on a wolf (with vipers as reins) to the god Balder's funeral pyre, is the motif on one of the stones in the Viking Age monument from Hunnestad in Skåne. Drawing after Danmarks runeindskrifter.

makes it possible for us to draw any direct conclusions. This pluralistic approach means that there is not just a single true interpretation for all hill-forts, or even that a single hillfort could only, and has been, interpreted in one mode.

If one would like to try out a concept, then the proper thing to do is to compare it with other concepts. For instance, what is the difference between a hill-fort and a grave? They seem to be two completely and unproblematically separate phenomena: one defends the living, the other takes custody of the dead. An excavation of a hill-fort at Hyltinge in the province of Södermanland $(100 \mathrm{~km}$ south- 
west of Stockholm), ${ }^{14}$ C-dated to 565-1020 A.D. (in calibrated values), is my startingpoint (Johansen \& Pettersson 1994). Within the hill-fort one grave with a cremated woman and a similar additional grave (only partly excavated and the sex not yet determined) were found. The graves, roughly dated to the Migration and Vendel periods (and as we believe connected with the hill-fort), lacked any kind of external indication. They quite simply looked like natural cavities in the rock. The reason we found the now totally excavated grave was that it had been torn up by the roots of a fallen tree trunk. In the outer room of the hill-fort there was a structure that preliminary has been interpreted as a place for a pyre. Less than 50 meters from the hill-fort was a round stonesetting filled with sharp-edged stones and surrounded by a row of larger kerb stones. It was placed on top of a rocky knoll (on the mountain), a location usually considered to indicate Bronze Age burials, but it was from the same part of the Iron Age as the other structures. It had been erected over a cremated woman and, according to the osteologi-

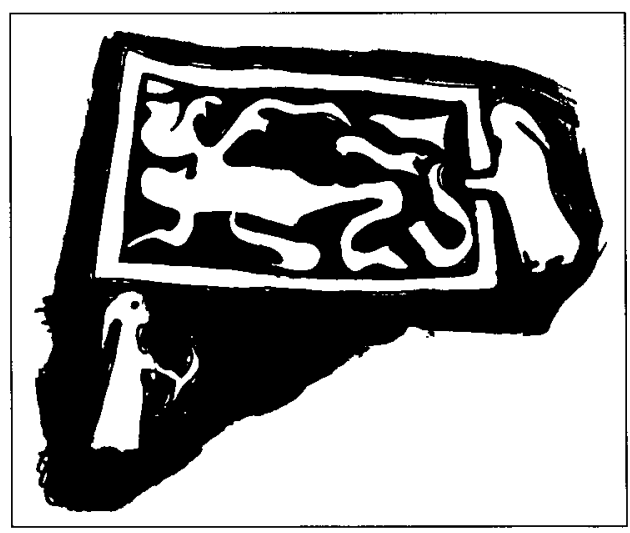

Fig. 8. Hunninge in Klinte parish, Gotland, from the Viking Age. This picture has been interpreted as Gunnar in the snake-pen. A woman is watching him being tormented. Below is a woman holding a winding object that resembles a serpent. Drawing after Nylén \& Lamm 1987. cal analysis, this woman was older than the woman inside the hill-fort. The graves were filled with splintered stones, probably brittleburnt (something which was also found in the walls of the hill-fort), as well as a separate layer probably containing material from a funeral pyre (Johansen \& Pettersson 1994 and quoted lit.).

The walls of the Swedish hill-forts quite often show traces of fire, and they have sometimes been vitrified. The hill-forts sometimes also contain "culture layers" in rock depressions. It is possible that in some cases these could be graves of the type discussed above, or the remains of a stage in the cremation ritual. The distinction between grave and hill-fort is thus not as simple and obvious as it may first seem. Therefore, if the definition of a grave isn't a structure covering a dead body, which would exclude for example stone circles, but instead a structure that marks out (distinguishes) the place where a dead body (or several) is kept, then such a hill-fort might just as well be classified as a grave. To this can be added that hill-forts occasionally show great similarities to cairns, through the "lining in" of a rock with its walls. These types of walls have often been considered as having slid down when they supposedly were purposely demolished. It is, however, not impossible that they were originally constructed in this way (Fig. 11). A parallel to this is the large Migration period mounds at Gamla (Old) Uppsala; their resemblance to Bronze Age mounds has been noted by several researchers. It seems as if at the beginning of the late Nordic Iron Age some monuments got an evident reference to Bronze Age design, and this is true not only for Sweden (cf. post-Roman conditions in England, Bradley 1993:117, Migration period in Norway, Hjörungdal 1991). A further similarity between the cairns and the hill-forts is that they are situated upon hills or mountains. Concerning hill-forts, this has been explained as strategic from a "military" point of view, but it can also be understood as a 
conscious and deliberate reference to earlier ages. The stone-setting next to the hill-fort in Hyltinge was of a type that usually contains a Bronze Age grave. It was also situated in a typical Bronze Age manner, and this is very unusual for graves from this late period.

The finds from the hill-forts, except from those which were probably proper settlements, are often ornaments belonging to the dress, ceramics e.g. strainers, spindle whorls, loom weights, strike-a-lights, blast nozzles, glass, etc. Arrow-heads and swords have also been found, but they are much less frequent. The finds are accordingly dominated by objects not usually specifically associated with men or violence. In other contexts these finds would instead have been seen as domestic and as indications of female presence and actions. On the other hand, the finds do not contradict the hypothesis that acts of war have occurred, or were expected to occur, and that this is why people stayed in the hillforts. Neither has the connection between the object and the supposed activity been tested. Finds of a ceramic strainer and loom-weights do not automatically imply cheese-making and weaving in a hill-fort. In my opinion, these objects have not really been interpreted in a satisfactory way, but have only been apprehended as indirect, passive traces of acts of war. To sum up, the objects and the few graves known today do indicate domestic uses rather than acts of war, as well as a stronger female presence than a male. There is also a connection with the Iron Age funerary rituals.

\section{A VISUAL AND STRUCTURAL INTERPRETATION}

A rather commonly accepted theory today is that material culture can be understood as communication, and this is the basis for the following attempt at an alternative interpretation. The monuments are consequently treated as parts of a conceptual structure and as "metaphorical vehicles" (Tilley 1991:67 pp). I will exemplify with the hill-forts. I

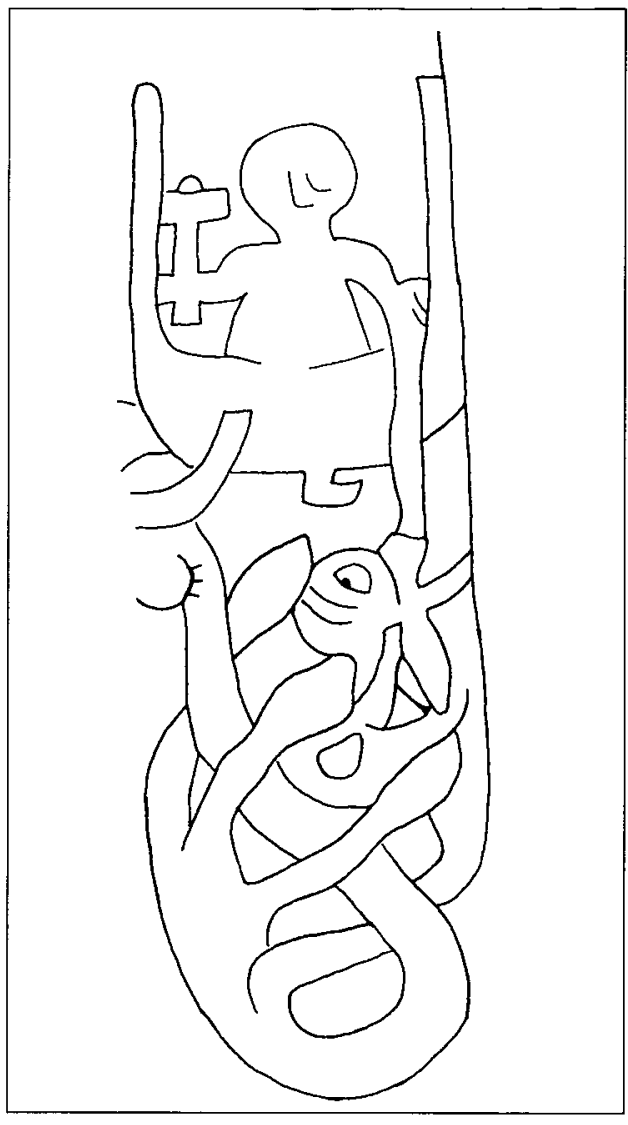

Fig. 9. This Viking Age runestone from Altuna, Uppland, depicts the well-known story of the god Thor's catch. Drawing after Vikingatidens $A B C$.

believe that visual resemblance (resemblance in shape) can be used to set up relations between different types of contemporaneous life forms. But visual resemblance can also show how meaning is created through metaphorical representation and metonymic association. According to this approach, nothing has a meaning in itself. Every object is defined by being delimited from what it is not, and at the same time it gets its meaning by being compared with that which it is not.

An application of these hypotheses to the source material demands a theory about, and 
a method for, the concept of transformation, since the phenomena we are going to compare are extremely different. That which is perceived as likeness in shape is not given in advance, but depends on the current complex of concepts (in this case the establishment of an identity). Visual transformation includes techniques for configuration, and those which are interesting in this context are what I call stylisation and miniaturisation. It is beyond the scope of this text to consider these concepts, but I think it is both feasible and rewarding to try to discuss stone walls, hill-forts and runestones as kinds of pictures and as "artistic" expressions, similar to words in a visual language. If they could be treated as configurations then they ought to, just as for example the rock-carving pictures, refer to meanings beyond the representations - "a second order language" (Olsen 1990:168 pp and quoted lit.). The mountain (or rock) and the hill-fort rampart do not solely refer to themselves, and a rock-carving moose not only to a real and living moose. The stone walls, the hill-forts and the runestones could in this way, through their material configurations, be attributed to other dimensions than just the functional. For instance, the hill-fort has (in the sense of being a structure of co-operation between mountain/rock and rampart) a visual message of its own, not necessarily identical with how the hill-fort was used. I do, however, believe that the use of a construction or an object can be a point of departure for interpretations, but without limiting them to a certain sphere. My point of departure is that the parts of the objects (monuments) can be considered as configurations and representations. Connections between monuments of different kinds and different parts of the life-world can thereby be established.

A transformation can also be linguistic and there is usually a co-operation between the linguistic and the visual. The kenning (a poetic paraphrase) is an excellent example of this (cf. Gurevich 1985, Andrén 1989:297,
1993:34 and quoted lit.). The imagery of the Nordic poetry embraces everything from simple paraphrases to vivid metaphors and abstruse riddles. This in turn draws attention to linguistic circumstances, to the etymology of the oldest known words for the structure that we today call hill-fort borg and sten (trans.. hill-fort/castle [cf. German burg] and stone/cliff). The word sten can allude to mountain - hill - rock, but also to a hill-fort. The place-name Steneby is often considered to come from a hill-fort somewhere within the properties of a farm. The runestone from Rö in northern Bohuslän (fifth century A.D.) mentions a StainawarijaR that possibly can be interpreted as the hill-fort (e.g. stone) defender (Hellberg 1975). The word borg (hillfort) is also cognate to the word berg (mountain - hill - rock). Researchers have noted that hills can have hill-fort names without having a hill-fort (Karlsson-Lönn 1992). Besides, the boundary between hill-fort and hill can be fairly diffuse in the stories. In Snorre's Edda we are told how Odin conquers the mead of poetry, i.e. the gift of poetry, from the giant Suttung, who had hidden it at a place called Hnitbjörg. Odin finds his way into the mountain through a borehole and by transforming himself into a serpent (1978:91 pp). This myth can be compared to "The Clashing Rocks, Symplegaderna, etc., "; they are at the centre of the world and it is there the hero can fetch the most miraculous things (Drobin 1991:113). Thus the mountain is a hillfort; things can be hidden inside the mountain and in the hill-fort, and if you are lucky you can get both in and out (cf. the runic inscription from Hennøy, Norge ca. 1200 A.D: "Here the men stayed who came from Giant land in a ship laden with gold, and it is inside this rock." trans. Kristjánsson 1988). There are also numerous examples of a connection between the mountain and the spiritual world (e.g. Helgafjäll in Eyrbyggarna's Saga 1978:11 p, see photo in Kristjánsson 1988:plate 15). This doesn't make it less interesting to presume that significations have 


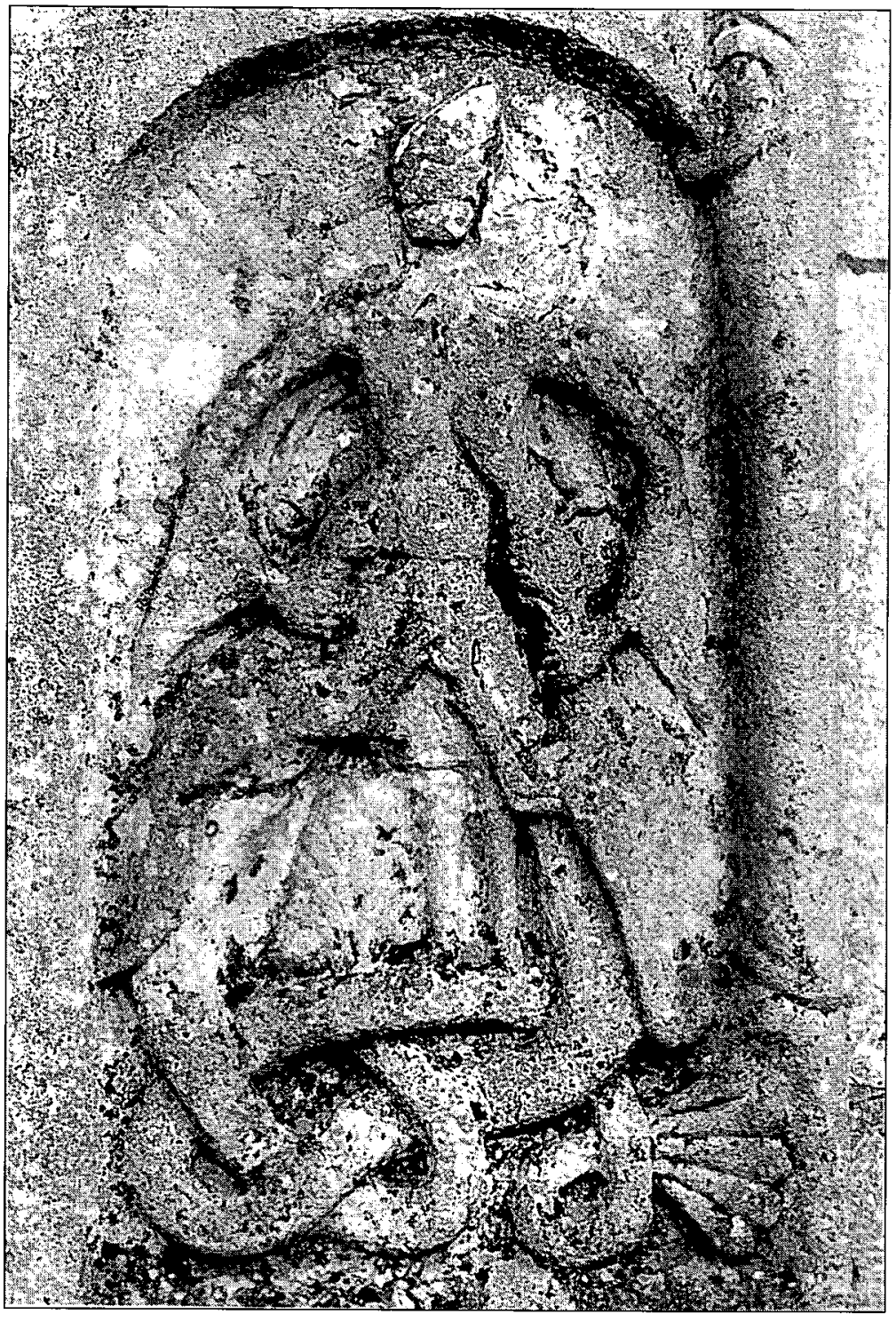

Fig. 10. In the northern porch of the early medieval church in Väte, Gotland, this sculpture can be seen representing two dragons suckling a woman. This is a motif that has been interpreted as Luxuria, i.e. Voluptuousness. Photo ATA, Bengt A. Lundberg $R I K$. been transferred from the mountain to the hill-fort and vice versa. Most of the hill-forts in Sweden are also situated on mountains where the rock-faces are often bare, not on gravel or moraine. The hill-fort in Hyltinge is, for example, situated around a cliff (in one direction vertical and five meters high) which constitutes the inner room. This ambiguity between hill-fort and cliff is in my opinion of the same kind as that used in the metaphorical interpretation. The metaphorical interpretation can thus be used as a basis for the understanding of the ideas about the world and the life-world during the late 
Nordic Iron Age.

What has been said so far can be summarised in an attempt at a structural analysis with the hill-fort at the centre. The active metaphor is still the establishment of an identity. A hill-fort consists of the mountain and the rampart in co-operation; but inasmuch as the mountain is a natural precondition and the rampart is created by human beings, I think that it is possible to see them, if not as contradictions in a classical sense, at least as parts in a binary relation. The following "oppositions" can be arranged: mountain:rampart are related to each other just as nature:culture. Man constructs the lifeworld, or the reality, through his acts and works. In the beginning there was nothing: out of a limitless continuum the delimited and perspicuous was created, and not even nature is a condition a priori. By separating and distinguishing places in nature man shapes culture (the perspicuous, controlled) but he also creates nature itself, that is, nature as a cultural product (cf. Lévi-Strauss 1969:xxix).

The stone rampart is related to the mountain as the dragon is to that which is guarded (and the stone walls to the infields). The dragon - stone wall - rampart is thus a separating/distinguishing limit in the limitless. On both sides of it are two aspects of nature: order and chaos. The dragon - stone wall - rampart is the guardian situated midway, which can be described as the condition of being liminal. The characteristics of the dragon are also ambiguous. The dragon is an anomaly, a category that doesn't fit in between the binary oppositions because it has characteristics from both sides, just as, for example, dawn and dusk are at the same time light and darkness and the mire is neither water nor land. It is interesting to note that the parents of the Midgård snake are a god (Loki) and a giantess (Angerboda) and the serpent is in this way neither a god nor a giant, or else it is both. The dragon is both the keeper of the boundaries and a transgressor. It can be found on the ground and in the ground/mountain, but also in the air. It can spit fire, but is sometimes found in water (cf. Beowulf) and it seems to be sexless fairly often (but cf. Fafner who was a man). Christopher Evans, who has studied British enclosures from the Neolithic, describe "the act of enclosure" as a creation of "a boundary which can simultaneously be a physical or cognitive barrier and a transitional zone." (1988:92). When you pass over that boundary there is a transformation; you go, for example, from the profane to the sacral, from the visible/everyday to the hidden/unusual. The dragon - stone wall - rampart also draws a boundary within and between man. In other words, the neutral body (with certain biological preconditions) is furnished with or acquires status: youth: adult, man:woman. But the dragon not only draws a boundary, it is also a mediator between the oppositions it has created (cf. Odner 1992:135 p 138): the dragon is at the same time the connection between man and woman.

I have argued earlier that the mountain and the stone rampart can be apprehended as connotative signs and thereby have a more far-reaching meaning. It is also possible to add woman:man, youth:adult, hidden:visible, internal:external to this chain of relations. The women are inside the mountain hill-fort - dragon in the stories. The female grave inside the hill-fort in Hyltinge is hidden in a rock-depression. The female grave outside the hill-fort contained a woman that was older than the woman inside the hill-fort. The man is a conqueror of riches, and in the stories this can be expressed as the conquering of women. Another link in the chain can be fire/air:water, death:life. The traces of fire are the split stones, the vitrified stone walls (ramparts) and the soot and coal in the depressions. The air is represented by the heavily fire-marked blast nozzles (Nordén 1929). If we consider the qualities and practical functions of the splintered stones, the ceramic strainer and the spindle whorls/loom 
weights, we could say that they represent different stages of transformation on the scale of nature:culture; the preparation of food and clothes can be compared to the transformation of the human body after death. The following is an attempt at a scheme over the relations that are expressed in the hill-fort:

\section{HILL-FORT}

NATURE

high sky
Delimited/Distinguished

\section{internal}

INFIELD

grow, breed

\begin{tabular}{|c|c|c|c|}
\hline \\
\hline & & un & \\
\hline Mountain & DEATH--Hidden & WOMAN & Youth \\
\hline
\end{tabular}

CULTURE

Stone wall/guardian/liminal/sexless/transformation/mediator/dragon

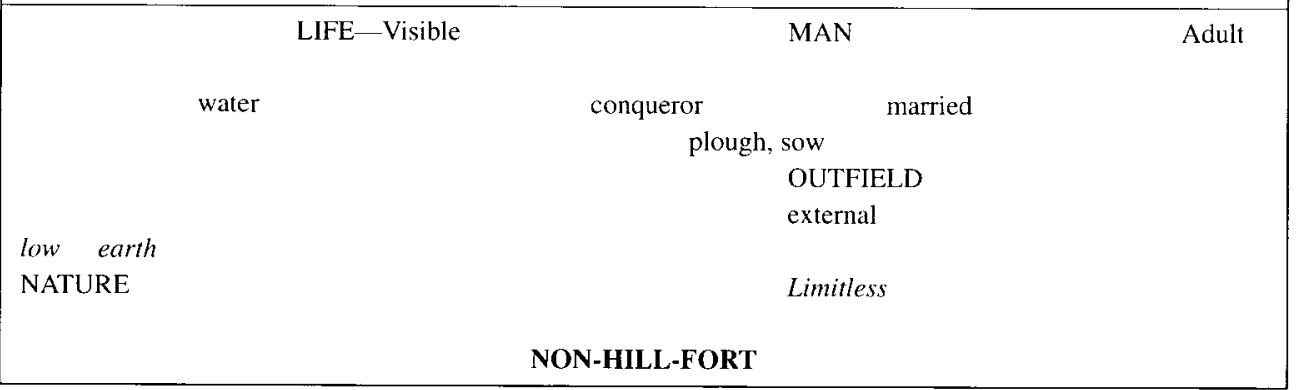

The relationship between male and female and between youth and adult (mature and immature) has, through the way described above, a correspondence in more practical, physical and earthly domains. Between man and the earth he cultivated there was the same struggle and resistance as between the sexes. The earth, the permanent and stationary, had to be plowed and sowed every year to yield crops. But the earth fought back and had to be persuaded and won in battle. The complex symbolic references of the gold foil figures may touch somewhat upon this theme. (It must be remembered that the fertility theme need not, or should not, be interpreted solely and literally as sexual. The sexual metaphor has a strong, evocative power well suited also to prosperity and richness in a more general sense.) However, it must be pointed out that this model is not thoroughly "logical". If woman and the reproduction of mankind were associated with the fertility of the earth, then woman and man should change places in this model. It may also seem very contradictory that the bare and unproductive, infertile mountain is made to represent its contradiction in this model. At the same time one of the foremost characteristics of the savage mind's way of thinking (Lévi-Strauss 1971) seems to be that the dynamics are created by the condition that everything carries the seed of its own contradiction. You could say that the savage thinking is organised around meaningful contradictions. In the myths it is possible for one and the same person to be both a man and an animal, young/beautiful and ugly/old and, for example, for wounds and jewellery (which disfigure and adorn the body respectively) to change places. Nothing is eternal. The fire is here associated with 
woman, which doesn't mean that this is valid for every situation. In other myths the fire is instead associated with something male, for instance, Surtr with his blazing sword (who is a kind of fire and sun god) while something feminine is associated with ice and water (Linke 1992:267 p and quoted lit.). The same is valid for the association between the internal and the female: in other contexts the external or Utgård (the outer farm, the outfields) is associated with the world of the women, the dead and the giants, and Midgard with the men, the gods and life (Clunies Ross 1991:43 in Odner 1992:138 p). The conclusion is that there are no absolute or eternal associations or attributes. This is so because they are tied to and determined by the situation and the context. The problem, if anything, is that the model is too one-dimensional and static (cf. Lévi-Strauss 1994: 66 ), it lacks the ability to show the concepts "in action" and in different contexts, not just as contrasts.

\section{THE TRANSFORMATIVE DRAGON}

Stone wall systems, hill-forts and rune-stones are united both visually and conceptually by the dragon as the representative for the concepts watch and protect, delimit and distinguish, exceed and transform. I will now try to interpret the monuments in their historical context.

The runestones can be, and have been, apprehended as juridical documents when dividing an estate. This is perhaps an anachronistic way of understanding them, but 1

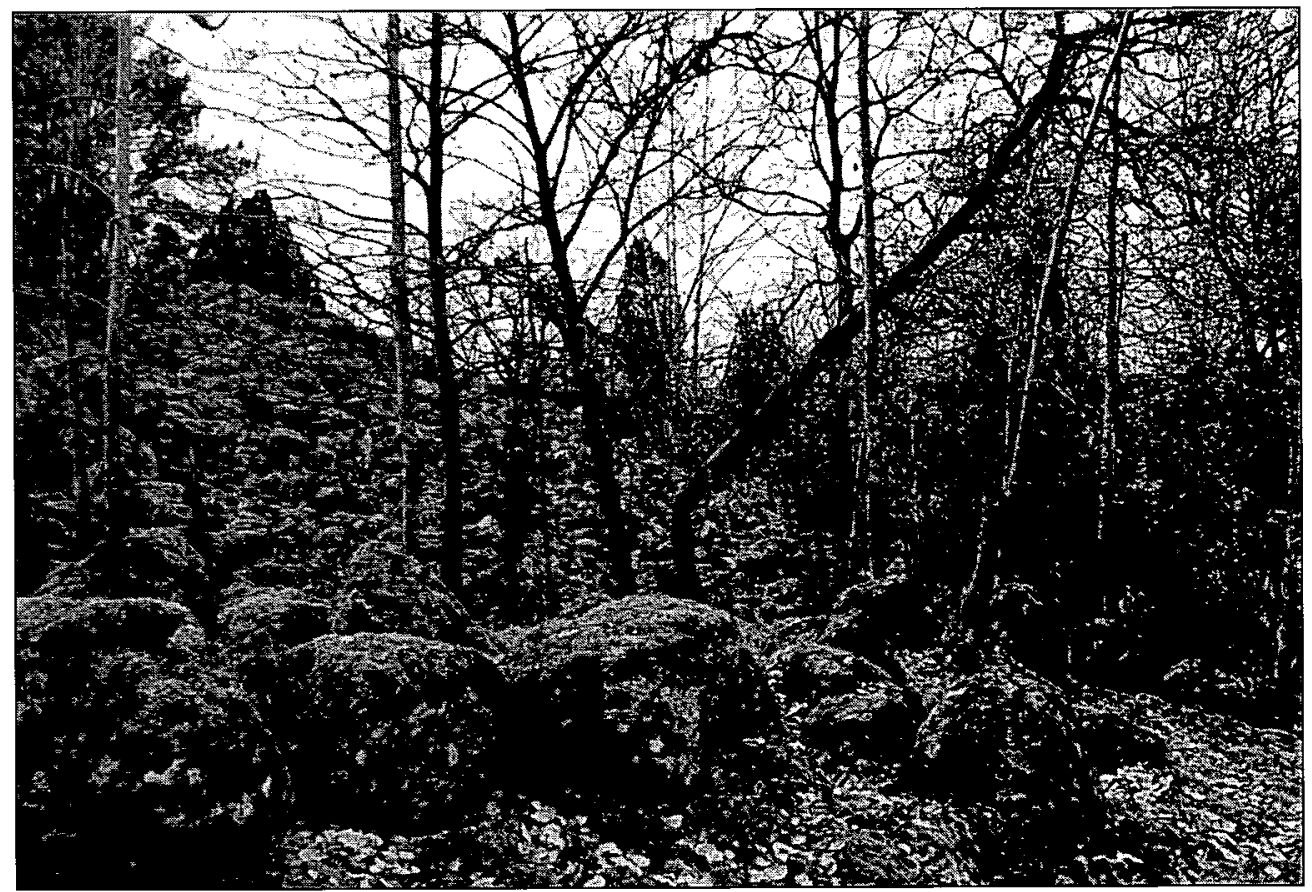

Fig. 11. Hill-fort/caim outside Eskilstuna in Södermanland. The structure consists of a ca. 15 meter high stone-packing lining the northern and the western face of a rocky knoll, i.e. the faces turned toward a river. The packing has both a brim and a kerb of stones. Walls are missing where it is easiest to get up. On the top is a levelled terrace. A small excavation revealed i.a. fragments of a ceramic strainer (Lorin 1988). Photo Björn Varenius. 
believe that the runic stone is best understood as a transmitter of meanings concerning inheritance of land, but also kinship, and this during a period when the traditional models of ownership and social organisation were changing. I also believe that the hillforts played a similar role about 500 years earlier. The runestone as well as the hill-fort can in this way be understood as an expression of both resistance and change.

On the runestones in the Mälar valley there is usually a dragon or serpentine arabesque. This is often arranged around the edges of the runestone. This distinguishes them from, for example, runestones in Denmark and Västergötland, but also from runestones from the earlier part of the Viking Age which have a more "textual" appearance. That it is the dragon and not some other animal or object that has been arranged around the edges of the runestones, cannot be explained with reference to the dragon's oblong shape, which is very suitable for this. It must have something to do with the meaning that the dragon conveyed (cf. Karlsson 1976). In my opinion, this runestone-dragon is a representation of the guardian also in this context. Some of the runestones were placed at the boundaries of properties, and this can also be seen as a way of referring to the guardian. They share this "boundary position" with the Viking Age picture stones on Gotland, which have been interpreted by Anders Andrén as "doors to other worlds" - places where people could cross the boundary between the world of the living and the dead (1989:294, 1993:33 pp).

The winding hill-fort rampart that guards a selected hilltop can be compared to a stylised dragon. In the hill-fort ramparts, and within the hill-fort, there are often traces of fire and in this way the hill-fort resembles a firespitting dragon. In the stories, the residence of the dragon is also usually in a mountain, or on top of a mountain. The hill-fort rampart guards and protects the internal from the external, just as the dragon. In its role as a guardian the dragon is midway, just as the stone walls.

Infield and outfield can be compared to the religious/philosophical concepts of Midgård/Asgård and Utgård (Gurevich 1985:47), that is, the world of humans and gods and the world of giants, respectively. These concepts were of great importance to the Nordic world of ideas during the late Iron Age, but also during at least the earlier part of the Middle Ages. In the sea surrounding the world was the Midgårdsorm, the guardian between order and chaos (cf. also the fight between Thor and the giant Hrugne at Grjotunagård, the stone wall farm at the border, Sturluson 1978:99). I take Mats Burström's hypothesis that the stone walls (from the early Iron Age) are representatives not only of a fossilised agricultural landscape but also of an ancient world of ideas separated into micro- and macrocosmos (1994:69 p), as a point of i $i_{-}$ parture. The delimited area inhabited and cultivated by a family, as well as the area they apprehended as Midgård, can then be compared to the delimited/distinguished and circumscribed/controlled area of a hill-fort. Christopher Tilley says, in his analysis of the Megalithic tombs in Västergötland, that "The tombs are, in effect, the landscape in miniature." (1991:74). And I believe that the hillforts are miniaturisations of the human lifeworld - the farm - the infields.

The runestone is in turn also a miniaturisation - a picture of the life space, the farm, that the family cultivated. The runestone dragon encompasses and protects the inherited family land, the odal, which was the most important inheritance (cf. Zachrisson 1994: $219 \mathrm{pp}$ ). This land could not be bought and sold unconditionally, because the individual identity and prestige depended on the personal kinship and on the place the family belonged to.

The dragon thus unites, both visually and as a concept, the stone wall systems, the hillforts and the runestones. The runestone can also be apprehended as a new material appli- 
cation of ideas similar to those which the hill-fort earlier was an expression of. Furthermore, both the hill-fort and the runestone can distinguish graves/grave areas.

The hill-fort did not have the same role during the Viking Age, and this can possibly be explained by the fact that the hill-fort earlier expressed the absence of an authority and not, as has been assumed so often, the occurrence of such (petty kings, defence systems, etc.). The hill-fort represented a society with its roots in the Bronze Age concerning production, gender roles, etc. This society "disappeared" at the middle of the first millennium A.D. The runestone, which can be characterised as a "protodocument", replaced "earlier practices, mainly carried out through the material culture." (Andrén 1993: 50). It was created in a society where an authority had started to develop, and this authority tried to monopolise both the external and the internal violence, at the same time as other internal means of solving conflicts were developed.

\section{SUMMARY}

The analytical tool in this article is the metaphor. It can, by being a syncretistic way of seeing, be used to compare the most surprising things with each other. It connects domains that have traditionally been apprehended as naturally divided and possible, or even only suited, to study separately. From the perspective of the history of science, its counterpart could be said to be the systems theory. It is true that I use domains with the same names as the "subsystems", but the important difference is that these domains exist in and through each other and not side by side. The process of creating an identity as a human being, of growing up and becoming a man or a woman, is in this way interrelated with the ownership and cultivation of land.

I have also tried to show how different source materials can be woven together to a "story". In this story there is the over-reaching theme of the construction of reality/the life-world through the separating and joining together of different domains. The purpose has been to try to illuminate something of how a societal totality could have been constructed, and briefly something about what was changed. In the construction of the lifeworld the metaphorical thinking parallels human beings, things, pictures, stories and the nature. But, the life-world is no more a reality than it is a social construction. It exists, as pictures of and inside each other, in a throng of reflections. At the same time there is a world independent of us, but we can never be objective and neutral observers of it. The world can only be understood as part of our social and historical relations.

\section{English revised by Laura Wrang.}

\section{REFERENCES}

Andrén, A. 1989. Dörrar till förgångna myter. En tolkning av de gotländska bildstenarna. In: Medeltidens födelse. Symposier på Krapperups borg 1. pp. 287-319. Lund.

- 1993. Doors to other worlds: Scandinavian death rituals in Gotlandic perspecitves. Journal of European Archaeology. Vol 1, spring. pp. 3356. Aldershot.

Arwidsson, G. 1977. Valsgärde 7. Die Gräberfunde von Valsgärde III. Uppsala.

Beowulf, 1988. Översättning Björn Collinder.

Burström, M. 1993. Silver as Bridewealth. An Interpretation of Viking Age Silver Hoards on Gotland, Sweden. Current Swedish Archaeology. Vol. I. pp. 33-37. Stockholm.

- 1994. Platsens arkeologi. Stensträngar i tankevärld och vardagspraktik. In: Odlingslandskap och fångstmark. En vänbok till Klas-Göran 
Selinge. pp. 67-74. Riksantikvarieämbetet. Stockholm.

Bradley, R. 1993. Altering the Earth. The Origins of Monuments in Britain and Continental Europe. The Rhind Lectures 1991-92. (Society of Antiquaries of Scotland Monograph Series Number 8). Edinburgh.

Brendalsmo, J. \& Röthe, G. 1992. Haugbrot eller de levendes forhold til de döde - en komparativ analyse. META 1992 1-2. pp. 84-119. Lund.

Clunies Ross, M. 1991. Pseudo-procreation myths in old Norse: an anthropological approach. In: Social approaches to Viking studies. Ed. R. Samson. pp. 35-44. Glasgow. Cruithne Press.

Conkey, M.W. \& Gero, J.M. 1991. Tensions, Pluralities, and Engendering Archaeology: An Introduction to Women and Prehistory. In: Engendering Archaeology. Women and Prehistory. pp. 3-30. Eds. J.M. Gero \& M.W. Conkey. Oxford.

Damsholt, N. 1985. Kvindebilledet $i$ dansk höjmiddelalder. København.

Danmarks runeindskrifter. 1942. Ved Lis Jacobsen og Erik Moltke. Text and atlas. København.

Den poetiska eddan. 1993. I översättning av Björn Collinder.

Dray, W. 1980. Perspectives on History. A Vision of World History: Oswald Spengler and the Life-Cycle of Cultures. pp. 99-139.

Drobin, U. 1991. Mjödet och offersymboliken i fornnordisk religion. In: Studier i religionshistoria tillägnade Åke Hultkrantz professor emeritus den 1 juli 1986. Löberöd.

Dumézil, G. 1973. The Gods of the Ancient Northmen. Ed. E. Haugen.

Egil Skallagrimssons saga. 1979. In: Isländska sagor översatta och utgivna av Hjalmar Alving. Gidlunds.

Evans, C. 1988. Act of enclosure: a consideration of concentrically organised causewayed enclosures. In: The Archaeology of Context in the Neolithic and Bronze Age: Recent Trends. pp. 65-79. Eds. J. C. Barrett \& I. A. Kinnes. Dept. Archaeology and Prehistory. University of Sheffield.

Eyrbyggarnas saga. 1978. In: Isländska sagor översatta och utgivna av Hjalmar Alving. Gidlunds.

Gilchrist, R. 1984. Gender and material culture.
The archaeology of religious women. Routledge.

Grambo, R. 1989. Unmanliness and seiðr: problems concerning the change of sex. In: Shamanism. pp. 103-113. Ed. M. Hóppal and O. J. von Sadovszky. Budapest, Los Angeles/Fullerton: ISTOR Books.

Gurevich, A.J. 1985. Categories of medieval culture. Routledge \& Kegan Paul. London.

Hedeager, L. 1991. Det europeiske hus. Romerne og germanerne. Copenhagen.

Hellberg, L. 1975. Ortnamnen \& den forntida sveastaten, (Inledning till NORNAS fjärde symposium Ortnamn och samhälle på Hanaholmen den 25-27/4). Uppsala.

Hjörungdal, T. 1991. Det skjulte kjönn. Patriarkal tradisjon og feministisk visjon i arkeologien belyst med fokus på en jernalderskontext. (Acta Archaeologica Lundensia. Series in $8^{\circ}$. Nr 19). Lund.

Hodder, 1. 1990. The Domestication of Europe. Structure and Contingency in Neolithic Studies. Oxford.

Johansen, B. \& Pettersson I-M. 1993. Från borg till bunker. Befästa anläggningar från förhistorisk och historisk tid. Riksantikvarieämbetet. Stockholm

- 1994. Nya perspektiv på fornborgar och gravar. En undersökning i Hyltinge, Södermanland. In: Odlingslandskap och fångstmark. En vänbok till Klas-Göran Selinge. pp. 163-178. Riksantikvarieämbetet. Stockholm.

Karlsson, L. 1976. Romansk träornamentik $i$ Sverige. Stockholm.

Karlsson-Lönn, M. 1992. Borgen, Borrevägg, Raneslott och Slottet. In: Borgar frän forntid och medeltid $i$ Västsverige. (Arkeologi i Västsverige 5.) Göteborg.

Kristjánsson, J. 1988. Eddas and sagas. Reykjavík. Lévi-Strauss, C. 1969. The Elementary Structures of Kinship. Beacon Press. Boston.

- 1971. Det vilda tänkandet. Stockholm.

- 1994. Lodjurets historia. Stockholm.

Linke, U. 1992. The theft of blood, the birth of men: cultural constructions of gender in medieval Iceland. In: From Sagas to Society. Comparative Approaches to Early Island. pp. 265288. Ed. Gíslí Pálsson. Hisarlik Press. Enfield Lock.

Lorin, O. 1988. Provutgräuning på Ärna fornborg. Antikvariskt topografiska arkivet, RA Ä, Stockholm (ATA) dnr 7037/88. Unpublished 
report.

Margeson, S. 1980. The Völsung legend in medieval art. Medieval Iconography and Narrative. A Symposium. pp. 183-211. Odense University press.

Meulengracht Sörensen, P. 1993. Fortalling og are. Studier $i$ islandinge-sagaerne. Aarhus universitetsforlag. Aarhus.

Mittner, L. 1955. Wurd. Das Sakrale in der Altgermanischen Epik. Bern.

Nordén, A. 1929. Östergötlands järnålder: Monografier. I. Enskilda fyndgrupper och problem. Stockholm.

Nylén, E. \& Lamm, J.P. 1987. Bildstenar.

Odner, K. 1992. Thórgunnas testament: a myth for moral contemplation and social apathy. In: From Sagas to Society. Comparative Approaches to Early Island. pp. 125-146. Ed. Gíslí Pálsson. Hisarlik Press. Enfield Lock.

Olsen, B. 1990. Roland Barthes: From Sign to Text. In: Reading material culture. Structuralism, Hermeneutics and Post-Structuralism. pp. 163-205. Ed. C. Tilley. Oxford.

Runstenar i Södermanland. Vägvisare till runristningar i Södermanlands län. 1984. Red. I. Wachtmeister. Södermanlands museum. Nyköping.

Saxo, 1986. Danmarks Riges Krönike. Danernes Bedrifter fra den aeldste tid og frem til omkring år 1200. København.

Snorres Edda. 1978. Översättning och inledning av Björn Collinder. Forum.
Spengler, O. 1990. Der Untergang des Abendlandes. Umrisse einer Morphologie der Weltgeschichte. (1923) München.

Steinsland, G. 1990. De nordiske gullblekk med parmotiv og norrøn fyrsteideologi. Collegium Medievale 1990/1. vol. 3, pp. 73-94.

Ström, Å. V. 1990. Sankt Göran - från myt till legend. ICO post 1990:4, pp. 43-48. Stockholm.

Thomas, J. \& Tilley, C. 1993. The Axe and the Torso: Symbolic Structures in the Neolithic of Brittany. In: Interpretative Archaeology. pp. 225-324. Ed. C. Tilley. Berg. Providence/Oxford.

Tilley, C. 1991a. Material Culture and Text. The Art of Ambiguity. London \& New York.

- 1991b. Constructing a Ritual Landscape. In: Regions and reflections. In honour of Märta Strömberg. (Acta Archaeologica Lundensia in $8^{\circ}$ No 20). pp. 67-79. Lund.

Vikingatidens $A B C .1981$. Statens historiska museer. Stockholm.

Völsungasagan. 1991. Helikon biblioteket 3. Översättning Inge Knutsson. Inledning Staffan Bergsten. Studentlitteratur. Lund.

Zachrisson, T. 1994. The Odal and its Manifestation in the Landscape. Current Swedish Archaeology, Vol. 2. pp. 219-238. Stockholm.

Yates, T. 1993. Frameworks for an Archaeology of the Body. In: Interpretative Archaeology. pp. 31- 72. Ed. C. Tilley. Berg. Providence/ Oxford. 